\title{
THE DAY OF THE WEEK EFFECT IN BORSA ISTANBUL; A GARCH MODEL ANALYSIS
}

\author{
Assoc. Prof. Mehmet Akif ÖNCÜ \\ Duzce University, Business Faculty, Duzce, Turkey (mehmetakifoncu@duzce.edu.tr) \\ Aslıhan ÜNAL* \\ Duzce University, Institute of Social Sciences, Duzce, Turkey (aslihanunal80@hotmail.com)
}

Res. Ast. Oğuz DEMIREL

Duzce University, Business Faculty, Duzce, Turkey (oguzdemirel@duzce.edu.tr)

\begin{abstract}
The aim of this study is to investigate the Day of the Week Effect (DWE) in Borsa Istanbul BIST-100 Index. For this purpose, the dataset of closing prices of the firms was gathered from 03.01.2005 to 06.11.2015. The data transformed to return series by taking logarithmic differences, and analyzed with GARCH $(1,1)$ Model. According to the findings, although the coefficients representing the returns of Monday and Thursday are statistically significant, the returns of the trading days of the week are equal. Consequently, for the related period, DWE did not detected in BIST-100 Index.
\end{abstract}

Keywords: Day of the Week Effect, GARCH Model, BIST-100 Index.

\section{BORSA İSTANBUL'DA HAFTANIN GÜNÜ ANOMALİSI; GARCH MODEL ANALIZI}

\begin{abstract}
ÖZET
Bu araştırmanın amact, Borsa İstanbul BIST-100 Endeksi'nde Haftanın Günü Anomalisinin varlı ̆̆ını araştırmaktır. Bu amaçla 03.01.2005-06.11.2015 döneminde firmaların kapanış fiyatları veri seti olarak kullanılmıstır. Veriler logaritmik farkları alınarak getiri serilerine dönüştürülmüş ve GARCH $(1,1)$ Model analizine tabi tutulmuştur. Analiz sonuçlarına göre Pazartesi ve Perşembe günlerinin getirilerini temsil eden katsayıların anlamlı çıkmasına rağmen, haftanın işlem günlerine ait ortalama getiriler birbirine eşittir. Sonuç olarak, incelenen dönemde BIST-100 endeksinde Haftanın Günü Anomalisine rastlanmamıştır
\end{abstract}

Anahtar Kelimeler: Haftanın Günü Anomalisi, GARCH Model, BIST-100 Endeksi.

* Corresponding author 


\section{Introduction}

The subject of this study "anomalies in stock markets" is examined in the field of behavioral finance that is emerged opposed to the efficient market hypothesis (EMH). EMH -attracted great attention in 1970s- asserts that as the stock prices reflect all the current information of stock market, future returns of these assets will not be predicted. Investors are rational and able to access to information. Hence, there will not be any contingency, and investors always take the right decision. The hypothesis started to be questioned in 1980s, because the fluctuations of the prices could not be explained adequately (Shiller, 2003).

Behavioral finance emerged to clarify these anomalies. Some researchers assert that people cannot always take right decisions, and psychological and sociological factors can affect their decisions. People can change their decisions according to these factors and in certain times they may tend to behave jointly. If an observation cannot be explained by the assumptions of EMH and cannot be explained logically it is so called "Anomaly". Anomalies are commonly examined in literature under 3 titles: calendar anomalies, firm anomalies, and prize anomalies

Researches on anomalies lead investors to develop strategies and gain over-expected returns. If an anomaly defined in a stock market, investors invest regarding the certain times that the anomalies detected and gain profit. As the behavioral finance attracted attention, calendar anomalies become the most researched anomaly type. The first research in the field was conducted in USA. Osborne (1962), Cross (1973), Roseff \& Kinney (1976), French (1980), Gibbons \& Hess (1981), and Ariel (1987) are the first researchers examined the calendar anomalies.

The subject of this study is to investigate the day of the week effect -a widely researched anomaly type- in Borsa Istanbul BIST-100 Index. In accordance with this purpose, the closing prices of the stocks that were traded in BIST-100 Index between the periods of 03.01.200506.11.2015 were taken as dataset. The closing prices transformed to return series by taking logarithmic difference and analyzed with GARCH $(1,1)$ Model.

\section{Literature Review}

\subsection{Efficient Market Hypothesis}

Efficient Market Hypothesis (EMH) was introduced by Fama in 1970. According to this hypothesis, the efficiency means that stock prices reflect all the current information and investors consider this information in their investment decisions. Stock prices exhibit a random distribution. That relationship between information and price -the price change according to every new information- leads to the fact that the future asset prices cannot be predicted. According to the Random Walk Theory the stock prices reflect merely the current day's information and are independent for the information spreads rapidly (Fama, 1970; Malkiel, 2003).

The assumptions of the EMH are (Fama, 1970):

- Investors are rational and always take the right decisions.

- Investors have full information.

- Investors search for maximizing their benefit. 
As the Fama's (1970) revealed exciting results, anomalies based on little dependencies were observed in his work (Schiller, 2003). Fama \& French (1998) examined the stock market returns in short and long periods and defined positive correlation in short term and negative correlation in long term between the current returns and past returns. In his 1998 work Fama examined whether stock prices react to information or not, and found that although unexpected returns, stock splits dividend actions, mergers, exchange listings, and announcements about primary market offerings lead to mobilization in stock prices, investors will not be able to gain abnormal returns, and explained the market condition in terms of reflection of prices as:

- All the participants can access to information at no cost,

- There are no transaction costs,

- All the participants agree that the stock prices reflect the information in the current state and in the future.

Fama (1998) asserts that the stated conditions are adequate but not necessary, and the efficiency of market will be provided as adequate number of investor access to information.

Malkiel (2003) defined "efficient market" as the markets investors will not be able to gain returns above the average unless they take risk above the average, and supports the view that stock markets do not have memory. Schwert (2003) stated that many prediction models disappear as they published in finance literature. The view that "prediction of stock returns" will lead investors to the aim of limitless profit. Hence, the market becomes a "money machine" that produces wealth. As such a situation is not possible in a stable economy, investor foster stock market returns to follow EMH (Timmerman \& Granger, 2004).

Psychologist Daniel Kahneman won a Nobel Prize in economics with Amos Tversky on their groundbreaking work "Prospect Theory: An Analysıs Of Decision Under Risk" Robert Shiller, Matthew Rabin, Sendhil Mullainathan, Esther Duflo and Raj Chetty are the researchers that won nobel prices for their work in behavioral finance Robert Shiller receives the Nobel Prize in economics for his work on asset bubbles and "irrational exuberance" in the stock market, and ironically he also shared the award with Eugene Fama, father of the "efficientmarket hypothesis," and another financial economist, Lars Hansen (Finkle, 2017).

\subsection{Stock Market Anomalies}

By the $21^{\text {st }}$ Century, many researchers and statisticians supported the view that stock market returns are predictable to some extent, and new generation scientists started to conduct researches that propose psychological and behavioral factors are also affect stock market prices (Malkiel, 2003). Neglecting the freewill is one of the critiques directed to EMH. Investors consider not only economic and financial indicators but also their inner world, past experiences, and perception of opportunities while making investment decisions (Taner \& Akkaya, 2005). In today's financial markets the incentives of fatalism, overconfidence, and joint action are effective (Cross et al., 2005).

Behavioral finance was developed in order to clarify the issues that EPH cannot explain, is a branch of finance that finance, psychology, and behavioral sciences are related considered 
(Fuller, 1998). Behavioral finance focuses on investors' irrational behaviors and psychological assumptions. If investors that are affected by sociological and psychological factors, they may change their decisions, or may overreact or underreact in some conditions. If EPH cannot explain that condition than it is called anomaly. Behavioral finance aims to identify the anomalies and to find out the reasons that lead to anomaly. As the anomalies are identified, investors will be able develop investment strategies.

Stock market anomalies are defined as the situations that cannot be explained by EMH and emerged due to the conditions as season, holiday, and liquidity preferences (Mbululu \& Chipeta, 2012). There are many types of stock market anomalies that are defined by researches but anomalies are generally identified under three titles: Calendar anomalies, firm size anomaly, and price anomaly. The types of anomalies that are mostly observed and their definitions are represented on Table 1.

Table 1: Stock Market Anomalies

\begin{tabular}{ll}
\hline Anomaly Types & Definitions \\
\hline 1. Calendar Anomalies & $\begin{array}{l}\text { The returns of each trading day of the week are not equal. } \\
\text { Monday effect -lower and negative returns on Mondays- } \\
\text { and Friday effect -higher returns on Fridays- are the most } \\
\text { observed DWE types in literature (Cross, 1973; Miralles } \\
\text { Marcelo \& Mirales Quiros, 2002; Brounen \& Ben Hamo, } \\
\text { - The Day of the Week } \\
\text { Effect (DWE) }\end{array}$ \\
$\begin{array}{ll}\text { Relatively higher returns on January among the other } \\
\text { months of the years (Wachtel, 1942; Rozeff \& Kinney, } \\
\text { 1976; Moosa, 2007). }\end{array}$ \\
$\begin{array}{l}\text { Relatively higher returns on the first four days and last four } \\
\text { days of the month (Lakonishok \& Smidt, 1988; Ziemba }\end{array}$ \\
$\begin{array}{l}\text { 1991; Cadsby \& Ratner, 1992). } \\
\text { - The Turn of the Month }\end{array}$ & $\begin{array}{l}\text { The rise of the stock prices the day before the holiday } \\
\text { (Fields, 1934; Meneu \& Pordo 2004; Marrett \& }\end{array}$ \\
Worthington, 2007). \\
\hline - Holiday Effect & $\begin{array}{l}\text { The negative correlation among the firm size and average } \\
\text { returns (Banz 1981; Keim, 1983; Balint, (2012). }\end{array}$ \\
\hline 2. Firm-size Anomalies & \\
\hline 3. Price Anomalies & $\begin{array}{l}\text { The under-reaction of investors to the announcements about } \\
\text { stock market prices in the period of 1 to 12 months (De } \\
\text { Bondt \& Thaler, 1985, 1987) }\end{array}$ \\
- Over-reaction & $\begin{array}{l}\text { The long-term (three to five years) over-reaction of investors } \\
\text { to especially dividend announcements (Barberis, Shleifer \& } \\
\text { Vishy, 1998) }\end{array}$ \\
\hline
\end{tabular}


Besides these 3 types of anomalies there are also anomaly types based on:

Price-Earnings $(\mathrm{P} / \mathrm{E})$ ratio: "P/E ratios are indicators of of the future investment performance of a security. Proponents of this price-ratio hypothesis claim that low $\mathrm{P} / \mathrm{E}$ securities will tend to outperform high P/E stocks" (Basu, 1977: 663).

The Price Earnings-Growth ratio: PEG ratio [PE]/[Short Term Earnings] "has become a popular means of combining prices and forecasts of earnings and earnings growth into a ratio that is used as a basis for stock recommendations (implicitly for comparing expected rates of return)" (Easton, 2004: 74).

\subsubsection{The Day of the Week Effect (DWE)}

The most observed anomaly type in stock market anomalies is 'the day of week effect' - expresses the situation that the returns of each trading day of the week are not equal (Tunçel, 2007).

Osborne (1962), Cross (1973), Rozeff \& Kinney (1976), French (1980), Gibbons \& Hess (1981), Ariel (1987) are the first researchers that examined DWE in United States. Osborne (1962) found evidences related to specific times of days, weeks and the year. Osborne (1962) defined non-random movements in Standart \& Poors Composite Index (S\&P). French (1980) defined a day of week effect and weekend effect in S\&P. Gibbons and Hess (1981) observed that the returns of stocks and treasury bonds were not constant through the week and defined that the returns on Mondays are low or negative.

After these researchers found evidence about the day of week effect in USA, researchers started to search for DWE worldwide. Miralles Marcelo \& Miralles Quiros (2002) defined the existence of DWE in Lisbon Stock Exchange. Kiymaz \& Berument (2003) conducted a research on Canada, Germany, Japan, United Kingdom, and USA Stock Exchanges and defined DWE in different days of the week in these markets. Sakalauskas \& Kriksciuniene (2007) searched for DWE in developing countries. For the analyze results conducted with the data of Vilnius OMX Index, it is defined that DWE was in tendency to disappear. Brounen \& Ben Hamo (2009) conducted a research with the data of prominent stock exchanges worldwide and defined anomalies on stock prices as higher returns on Fridays and lower on Mondays. Angelovska (2013) searched for calendar anomalies in Macedonian Stock Exchange and defined a DWE on Wednesdays.

Especially for the last two decades some researchers as Kamara (1997), Dimson \& Marsh (1999), Brusa et. al. (2000), Mehdian \& Perry (2002) found evidences in terms of anomalies are disappearing (Brounen \& Ben Hamo, 2009). 


\subsubsection{The Day of the Week Effect in Borsa Istanbul.}

Istanbul Stock Exchange (ISE) was founded in December 1985. ISE and Istanbul Gold Exchange merged under "Borsa Istanbul" in April 2013 ${ }^{1}$. BIST-100 Index is the basic index for Istanbul Share Market. It consists of 100 shares selected from the firms that are traded in Star Market $^{2}$ and Main Market ${ }^{3}$, real estate investment trusts and venture-capital trusts ${ }^{4}$.

Many researches were carried out to define DWE effect in Borsa Istanbul. Karan (1994), Aydoğan (1994), Balaban (1995), Bildik (2000), Özmen (1997), Demirer \& Karan (2002), Karan (2002), Karan \& Uygur (2001)'s findings commonly indicate that the returns on Fridays are higher than the other trade days of the week, and though they are not statistically significant, negative returns on Mondays and Tuesdays, and Atakan (2008) defined negative returns on Mondays. Karan (2001) reviewed the recent studies on Istanbul Stock Exchange (ISE) and supported that ISE is not an efficient market. Metin, Muradoğlu \& Yazıcı (1997) conducted a Research on ISE in the period of 1988-1996 and observed both Monday and Friday Effects. Ergül et. al. (2008) examined ISE composit-100 Index for the period between 1988 and 2007 and found that it is possible to gain daily abnormal returns fort he market is not efficient. Hepşen (2012) searched for anomalies in ISE Real Estate Investment Trust (REIT) Index and defined a Monday Effect. Aksoy \& Ulusoy (2015) examined the return and volatility behavior in REIT and BIST-100 Indexes in the period from 2000 to 2014 and defined that calendar anomalies still exists for both indexes, solely DWE for returns disappeared in BIST-100 Index.

Researches on DWE in BIST broadly support the view that BIST is an inefficient market. Based on these findings, defining the recent situation of the market was aimed in this research. For this purpose, a recent period of 03.01.2005 - 06.11.2015 was decided on, and basic index -BIST 100- was selected to analyze.

\section{Methodology}

\subsection{Data}

The closing prices of the stocks were used in this research that was traded in BIST-100 Index between the periods of January 3, 2005 - November 6, 2015. The data was gathered from the official web site of Central Bank of Turkish Republic. The return series was used in analyze evaluated by taking logarithmic differences of closing prices. The purpose of taking logarithmic differences is to make the data stationary (Miralles-Marcello \& Miralles-Quiros, 2002). The logarithmic differences of 2058 observations were calculated as follows:

\footnotetext{
1 Retrieved from http://www.borsaistanbul.com/kurumsal/borsa-istanbul-hakkinda/tarihsel-gelismeler

2 Star Market 1st group: Stock market value $\geq 250.000 .000 \mathrm{TL}$, total market value $\geq 1.000 .000$. $000 \mathrm{TL}$; nominal value $/$ min. capital rate $=5 \%$, equity / capital rate $\geq 0,75$ Star Market $2^{\text {nd }}$ group: Stock market value $\geq 100.000 .000$ $\mathrm{TL}$, total market value $\geq 400.000 .000 \mathrm{TL}$, nominal value $/ \mathrm{min}$ capital rate $=10 ; \%$ equity $/$ capital rate $\geq 1$

3 Main Market 1st group: Stock market value $\geq 50.000 .000$, nominal value $/ \mathrm{min}$. Capital rate $=15 \%$ equity $/$ capital rate $\geq 1$ Main Market 2nd group: Stock market value $\geq 25.000 .000$, nominal value $/ \mathrm{min}$. capital rate $=\% 25$, equity / capital rate $\geq 1,25$

4 REtrieved from: http://www.borsaistanbul.com/docs/default-source/endeksler/bist-pay-endeksleri-temel-kurallari. pdf?sfvrsn=10
} 
$R_{t}=\ln \frac{I_{t}}{I_{t-1}}$

$\mathbf{R}_{\mathbf{t}}=$ Return of BIST-100 index between two closing time on day $\mathrm{t}$.

$\mathbf{I}_{\mathbf{t}}=$ Closing price of BIST-100 index on day $\mathrm{t}$.

$\mathbf{I}_{\mathbf{t}-1}=$ Closing price of BIST-100 index on day $\mathrm{t}-1$.

The descriptive statistics of return series are displayed on Table 2

Table 2: Descriptive Statistics of Return Series

\begin{tabular}{lc}
\hline Mean & 0.000311 \\
\hline Median & 0.000977 \\
\hline Maximum & 0.121272 \\
\hline Minimum & -0.110638 \\
\hline Std. Dev. & 0.017417 \\
\hline Skewness & -0.308303 \\
\hline Kurtosis & 6.620313 \\
\hline Jarque-Bera & $\mathbf{1 4 0 9 . 3 7 8}$ \\
\hline Probability & $\mathbf{0 . 0 0 0 0 0 0}$ \\
\hline Sum & 0.779439 \\
\hline Sum sq. dev. & 0.760514 \\
\hline Observations & 2508
\end{tabular}

Statistics were shown on Table 1, indicates that return series exhibit normal distribution (JB statistics is significant on level 0.01). According to null hypothesis series exhibit normal distribution. The hypothesis is rejected. Hence, return series do not exhibit normal distribution. This situation is related especially to the high kurtosis coefficient (Silva, 2010). 3.2. Model

Autoregressive Conditional Heteroskedastic (ARCH) Model is the process introduced by Engel (1986) allows the conditional variance to change over time as a function of past errors leaving the unconditional variance constant. As ARCH offers a solution for the assumption of constant variance, it has some conflicts that often will lead to violation of the non-negativity constraints derived from estimating a totally free lag distribution. In order to solve this problem Bollerslev (1986) developed Generalized Regressive Conditional Heteroskedasticity (GARCH) Model that is a natural generalized form of ARCH (Bollerslev, 1986).

Heteroskedasticity indicates "a formal model of the process that generating the different variances, these difficulties are easily eliminated by performing an appropriate linear transformation on the data based on this model. However, "even when such model is available, it may be incorrect" (White, 1980:817). As heteroskedasticity is a commonly observed 
behavior in time series, Ordinary Least Squares (OLS) Methodology does not operate efficient under heteroskedasticity, and the findings are not reliable. For this reason, in this research it is preferred to employ GARCH $(1,1)$ - the simplest and often very useful form of GARCH as Bollerslev (1986) asserted.

Main regression model with 5 dummies was constructed in order to test DWE, as follows:

$$
R_{t}=\sum_{i=1}^{5} \alpha_{i} D_{i t}+\varepsilon_{t}
$$

$\mathbf{R}_{\mathbf{t}}$ : The average daily return

$\boldsymbol{\alpha}$ : The average daily return of each trading day

$\mathbf{D}_{\mathbf{i}}$ : Dummy variables, representing the trading days of the week $\left(\mathrm{D}_{1}\right.$ is equal to 1 on Mondays, 0 for all other days; $\mathrm{D}_{2}$ is equal to 1 on Tuesdays, 0 for all other days; $\mathrm{D}_{3}$ is equal to 1 for Wednesdays and 0 for all other days; D4 is equal to 1 for Thursdays and 0 for all other days, D5 is equal to 1 for Fridays and 0 for all other days).

\section{$\varepsilon_{\mathrm{t}}:$ Error term}

Dummy variables -represented as $\mathbf{D}_{\mathbf{i}}$ in the equation (2)- are independent variables which take the value of either 0 or 1 . Just as a, a dummy variable is a numeric stand-in for a qualitative fact or a logical proposition" (Garavaglia, \& Sharma, 1998:43).

Error term -represented as $\boldsymbol{\varepsilon}_{\mathrm{t}}$ in the equation (2) and also called as "residual"- represents "the difference between the actual value of the dependent variable and the estimated value of the dependent variable at the regression equation" (Zikmund, 2000:519).

The regression model is formed to test the following hypothesis indicating that the average returns of each trading day are equal.

$$
\mathrm{H}_{0}: \alpha_{1=} \alpha_{2=} \alpha_{3=} \alpha_{4=} \alpha_{5}
$$

At first, Ordinary Least Squares (OLS) Methodology was applied to the model, but it was defined that error terms exhibit heteroskedasticity. To eliminate this problem, following GARCH $(1,1)$ Model was formed:

$$
\begin{aligned}
& R_{t}=\sum_{i=1}^{5} \alpha_{i} D_{i t}+\varepsilon_{t} \\
& \varepsilon_{t} \mid \varphi_{t-1}: N\left(0, h_{t}\right) \\
& h_{t}=\gamma_{0}+\gamma_{1} \varepsilon_{t-1}^{2}+\gamma_{2} h_{t-1}
\end{aligned}
$$


$\mathbf{R}_{\mathbf{t}}$ : The average of BIST-100 index between two closing time on day $t$.

$\boldsymbol{\alpha}_{i}$ : The average return of each trading day of week.

$\mathbf{D}_{\mathbf{i}}$ : Dummy variables, representing the trading days of the week $\left(\mathrm{D}_{1}\right.$ is equal to 1 on Mondays, 0 for all other days; $\mathrm{D}_{2}$ is equal to 1 on Tuesdays, 0 for all other days; $\mathrm{D}_{3}$ is equal to 1 for Wednesdays and 0 for all other days; D4 is equal to 1 for Thursdays and 0 for all other days, D5 is equal to 1 and 0 for all other days).

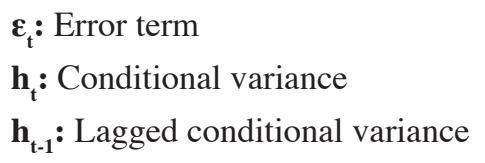

The equation represents that error terms exhibit conditional distribution at the dataset of $\phi$ on " $\mathrm{t}-1$ " time, and the conditional variance is depended to lagged square of error terms and lagged conditional variance.

\section{Findings}

\subsection{GARCH $(1,1)$ Model findings on DWE effect in BIST-100 index}

The GARCH $(1,1)$ Model was analyzed by Eviews 8.0 software. It is defined that the problem of heteroskedasticity is eliminated, and the model do not include autocorrelation. The findings of the analysis are displayed on Table 3.

Table 3: GARCH $(1,1)$ Model Analysis Findings

\begin{tabular}{lccc}
\hline \multicolumn{1}{c}{ Variables } & Coefficients & Statistics $\mathbf{z}$ & p values \\
\hline Monday $\left(\mathrm{D}_{1}\right)$ & 0.001531 & 2.454101 & $\mathbf{0 . 0 1 4 1 * *}$ \\
\hline Tuesday $\left(\mathrm{D}_{2}\right)$ & 0.000729 & 1.062741 & 0.2879 \\
\hline Wednesday $\left(\mathrm{D}_{3}\right)$ & 0.001006 & 1.518616 & 0.1289 \\
\hline Thursday $\left(\mathrm{D}_{4}\right)$ & 0.001775 & 2.846515 & $\mathbf{0 . 0 0 4 4}$ \\
\hline Friday $\left(\mathrm{D}_{5}\right)$ & 0.000923 & 1.308997 & 0.1905 \\
\hline
\end{tabular}

*significant at $0.01 \%$ level. **significant at $0.05 \%$ level

Table 3 indicates that the returns on Mondays (D1) have statistically significant effect on average returns (R) at the level of 0.05 , and on Thursdays (D4) at the level of 0.01 . These findings suggest that there may be Monday and Thursday Effects on BIST-100 Index for the related period.

\subsection{Wald Test Findings}

The Wald test statistics is the estimation of unrestricted regression without imposing the coefficient restrictions specified by the null hypothesis. It measures how close the unrestricted estimation satisfies the restrictions under the null hypothesis (Ergün\&Göksu, 2013: 138). The 
following hypothesis was tested by Wald Test to examine the existence of DWE in BIST-100 Index, and the results are presented on Table 4.

$$
H_{0}=\alpha_{1}=\alpha_{2}=\alpha_{3}=\alpha_{4}=\alpha_{5}
$$

The null hypothesis represents that the returns of each trading day of the week are equal.

Table 4: WALD Test Findings

\begin{tabular}{lccc}
\hline Test Statistic & Value & df & Probability \\
\hline Chi-square & 1.872846 & 4 & 0.7591 \\
\hline
\end{tabular}

According to Wald Test results $\mathrm{H}_{0}$ hypothesis was confirmed at the significance level of $0.05(0.7591<0.05)$. Hence, average returns of each trading day of the week are equal to each other, and BIST-100 is an efficient market for the related period.

\section{Conclusion}

DWE, one of the most researched anomaly types, is examined in this research. According to the findings of GARCH $(1,1)$ Model analyze, it is defined that BIST-100 index is an efficient market. This result does not support the findings of the researches that returns on Mondays are negative and lower and returns Fridays are higher than the other trading days of the week (Ergül et. al., 2008, Abdioğlu \& Değirmenci, 2013), returns of Mondays are lower than other trading days of the week (Atakan, 2008; Hepşen, 2012; Konak \& Kendirli, 2014), returns on Fridays are higher than the other trading days (Karan, 1994; Aydoğan, 1994; Balaban, 1995; Bildik, 2000; Özmen, 1997; Demirer \& Karan, 2002; Karan \& Uygur, 2001; Karan 2002), returns of Tuesdays are lower and negative and returns of Fridays are higher than other trading days of the week (Muradoğlu \& Oktay, 1993; Bildik, 2000). Though few, there are also researches that DWE was not detected (Aybar, 1993; Tunçel, 2007; Başdaş, 2011).

As a more recent period was examined in this research, the result can be interpreted as DWE is getting disappeared in BIST-100 index. In international literature, there are also researches as Dimson \& Marsh (1999), Kamara (1997), Brusa et. al. (2000), Mehdian \& Perry (2000) asserting that Monday Effect has disappeared in USA (Brounen \& Ben Hamo, 2009).

The future researches that consider different indexes and other calendar anomaly types will introduce more evidence about the efficiency of BIST.

\section{References}

Abdioğlu, Z., \& Değirmenci, N. (2013). İstanbul menkul kıymetler borsasında mevsimsel anomaliler. Business and Economics Research Journal, 4(3), 55-73.

Aksoy, M., \& Ulusoy, V. (2015). Analysis of relative return behaviour of Borsa İstanbul reit and Borsa İstanbul 100 index. Journal for Economic Forecasting, (1), 107-128. 
Angelovska, J. (2013). An econometric analysis of market anomaly - day of the week effect on a small emerging market. International Journal of Academic Research in Accounting, Finance and Management Sciences, 3(1), 314-322.

Ariel, R. A. (1987). A monthly effect in stock returns. Journal of Financial Economics, 18(1), 161-174.

Atakan, T. (2008). İstanbul Menkul Kıymetler Borsası'nda Haftanın Günü Etkisi ve Ocak ayı anomalilerinin Arch-Garch modelleri ile test edilmesi. Journal of the School of Business Administration, Istanbul University, 37(2), 98-110.

Aybar, C. B. (1993). Day of the week anomaly: A contrary evidence from Istanbul Stock Exchange, İ. Ü. Issletme Fakültesi Dergisi, 22(1), 157-168.

Aydoğan, K. (1994). Hisse senedi fiyatlandırılmasında aykırılıklar. İktisat, İşletme ve Finans Dergisi, 9(100), 83-89.

Balaban, E. (1995). Day of the week effects: New evidence from emerging stock market. Applied Economics Letters, 2(5), 139-143.

Balint, C. (2012). How does the Size Effect Influence the Romanian Investors' strategy?. Procedia Economics and Finance, 3, 722-727.

Banz, R. (1981). The relationship between return and market value of common stocks. Journal of Financial Economics, 9, 3-18.

Barberis, N., Shleifer, A., \& Vishny, R. (1998). A model of investor sentiment. Journal of Financial Economics, 49(3), 307-343.

Basu, S. (1977). Investment performance of common stocks in relation to their price earnings ratios: A test of the efficient market hypothesis. The Journal of Finance, 32(3), 663-682.

Başdaş, Ü. (2011). The day of the week effect for Istanbul stock exchange: A stochastic dominance approach. Journal of Applied Finance \& Banking. 1(4): 223-238.

Bildik, R. (2000). Hisse senedi piyasalarında dönemsellikler ve IMKB üzerine ampirik bir çalışma. İstanbul: İstanbul Menkul Kıymetler Borsası Yayınları.

Bollerslev, T. (1986). Generalized autoregressive conditional heteroscedasticity. Journal of Econometrics, (31): 307-327.

Brounen, D., \& Ben-Hamo, Y. (2009). Calendar anomalies: The case of international property shares. The Journal of Real Estate Finance and Economics, 38(2), 115-136.

Cadsby, C. B., \& Ratner, M. (1992). Turn-of-month and pre-holiday effects on stock returns: Some international evidence. Journal of Banking \& Finance, 16(3), 497-509.

Cross, F. (1973). The behavior of stock prices on Fridays and Mondays. Financial Analysts Journal, 29(6), 67-69.

Cross, R., Grinfeld, M., Lamba, H., \& Seaman, T. (2005). A threshold model of investor psychology. Physica A: Statistical Mechanics and its Applications, 354, 463-478.

De Bondt, W. F. M., \& Thaler, R. (1985). Does stock market overreact?. Journal of Finance, 40(3), 793-805.

De Bondt,W. F. M., Thaler, R. (1987), Further evidence on investor overreaction and stock market seasonality. Journal of Finance, 42, 557-581. 
Demirer, R., \& Karan, M. B. (2002). An investigation of the day-of-the-week effect on stock returns in Turkey. Emerging Markets Finance \& Trade, 47-77.

Easton, P. D. (2004). PE ratios, PEG ratios, and estimating the implied expected rate of return on equity capital. The Accounting Review, 79(1), 73-95.

Ergül, N., Akel, V. \& Dumanoğlu, S. (2008). İMKB'de günlük anomaliler. Marmara Üniversitesi İIBF Dergisi, 25(2): 601-629.

Ergün, U., \& Göksu, A. (2013). Applied Econometrics with Eviews Applications. Bosnia and Herzegovina: International Burch University.

Fama, E. F. (1970). Efficient capital markets: A review of theory and empirical work. The journal of Finance, 25(2), 383-417.

Fama, E. F. (1998). Market efficiency, long-term returns, and behavioral finance. Journal of Financial Economics, 49(3), 283-306.

Fama, E. F., \& French, K. R. (1988). Dividend yields and expected stock returns. Journal of Financial Economics, 22(1), 3-25.

Fields, M. J. (1934). Security prices and stock exchange holidays in relation to short selling. Journal of Business, 7(3), 328-338.

Finkle, V. (2017). Issue: Behavioral Economics. SAGE Business Researcher.

French, K. R. (1980). Stock returns and the weekend effect. Journal of Financial Economics, 8(1), 55-69.

Fuller, R. J. (1998). Behavioral finance and the sources of alpha. Journal of Pension Plan Investing, 2(3), 291-293.

Garavaglia, S., \& Sharma, A. (1998). A smart guide to dummy variables: Four applications and a macro. In Proceedings of the Northeast SAS Users Group Conference (pp. 43).

Gibbons, M. R., \& Hess, P. (1981). Day of the week effects and asset returns. Journal of Business, 579-596.

Hepşen, A. (2012). Calendar anomalies and Turkish Real Estate Investment Trusts (REITs). International Journal of Economics and Finance, 4(3), 230.

Karan, M.B. (1994). İstanbul Menkul Kıymetler Borsası'nda Hafta Sonu Etkisi. Yaklaşım, 2, 99-109.

Karan, M. B. (2001). İstanbul Menkul Kıymetler Borsası anomalileri. Ege Academic Review, $1(2), 83-94$.

Karan, M. B. (2002). Istanbul Menkul Kiymet Borsası sektör endekslerinde haftanın günleri ve Ocak ayı etkilerinin test edilmesi. İsletme ve Finans Dergisi, 17(90), 51-59.

Karan, M. B., \& A. Uygur (2001) İstanbul Menkul Kıymetler Borsası'nda haftanın günleri ve Ocak ayı etkilerinin firma büyüklüğü açısından değerlendirilmesi. A.Ü. Siyasal Bilgiler Fakültesi Dergisi, 56 (2), 103-116.

Keim, D. B. (1983). Size-related anomalies and stock return seasonality: Further empirical evidence. Journal of Financial Economics, 12(1), 13-32.

Kiymaz, H., \& Berument, H. (2003). The Day of the Week Effect on stock market volatility and volume: International evidence. Review of Financial Economics, 12(4), 363-380. 
Konak, Ö. G. F., \& Kendirli, S. (2014). Küresel finansal kriz sürecinde BİST 100 endeksinde Haftanın Günleri Etkisinin analizi. Süleyman Demirel Üniversitesi İktisadi ve İdari Bilimler Fakültesi Dergisi, 19(2), 275-286.

Lakonishok, J., \& Smidt, S. (1988). Are seasonal anomalies real? A ninety-year perspective. Review of Financial Studies, 1(4), 403-425.

Malkiel, B. G. (2003). The efficient market hypothesis and its critics. Journal of Economic Perspectives, 17(1), 59-82.

Marrett, G. J., \& Worthington, A. C. (2007). An empirical note on the Holiday Effect in the Australian stock market, 1996-2006. Applied Economics Letters, 16(17), 1769-1772.

Mbululu, D. (2010). Day of the Week Effect: Evidence from nine sectors of the South African stock market. Master's Thesis, South Africa, Rhodes University. Faculty of Commerce, Economics \& Economic History.

Mbululu, D., \& Chipeta, C. (2012). Day of the Week Effect: Evidence from the nine economic sectors of the JSE. Investment Analysts Journal, 41(75), 55-65.

Meneu, V., \& Pardo, A. (2004). Pre-holiday effect, large trades and small investor behaviour. Journal of Empirical Finance, 11(2), 231-246.

Metin, K., Muradoğlu, G. \& Yazıcı, B. (1997). An analysis of the 'Day of the Week Effect' on the İstanbul Stock Exchange. The ISE Review, 1(4), 15-25.

Miralles Marcelo, J. L., \& Miralles Quirós, M., M. (2002). An empirical analysis of the Weekday Effect on the Lisbon stock Market over trading and non-trading periods. Portuguese Review of Financial Markets, 3(2), 5-14.

Moosa, I. A. (2007). The vanishing January effect. International Research Journal of Finance and Economics, 7(1), 92-102.

Muradoğlu, G. \& Oktay, T. (1993). Hisse senedi piyasasında zayıf etkinlik: Takvim anomalileri. Hacettepe Üniversitesi IIBF Dergisi, 11, 51-62.

Osborne, M. F. M. (1962). Periodic structure in the brownian motion of stock prices. Operations Research, 10(3), 345-379.

Özmen, T. (1997). Dünya borsalarında gözlemlenen anomaliler ve İMKB üzerine bir deneme. Ankara: Publication of the Capital Market Board of Turkey No: 61.

Rozeff, M., \& Kinney, W. (1976). Capital market seasonality: The case of stock market returns. Journal of Financial Economics, 3(4), 379-402.

Sakalauskas, V., \& Kriksciuniene, D. (2007). The impact of daily trade volume on the Day of the Week Effect in emerging stock markets. Information Technology and Control, 36(1A), 152-158.

Schwert, G. W. (2003). Anomalies and market efficiency. Handbook of the Economics of Finance, 1, 939-974.

Shiller, R. J. (2003). From efficient markets theory to behavioral finance. Journal of economic perspectives, 17(1), 83-104.

Silva, P. M. (2010). Calendar 'anomalies' in the Portuguese stock market. Investment Analysts Journal, 39(71), 37-50. 
Taner, B., \& Akkaya, G. C. (2005). Yatırımcı Psikolojisi ve Davranışsal Finans Yaklaşımı. Muhasebe ve Finansman Dergisi, (27), 47-54.

Timmermann, A., \& Granger, C. W. J. (2004). Efficient Market Hypothesis and forecasting. International Journal of Forecasting, 20, 15-27.

Tunçel, A. K. (2007). IMKB'de Haftanın Günü etkisi. Akdeniz Üniversitesi İktisadi ve İdari Bilimler Fakiultesi Dergisi, 7(13), 252-265.

Wachtel, S. B. (1942). Certain observations on seasonal movements in stock prices. Journal of Business of the University of Chicago, 184-193.

White, H. (1980). A Heterokedasticity-consistent covariance matrix estimator and a direct test for heteroskedasticity. Econometrica, 48 (4), 817-838.

Ziemba, W. T. (1991). Japanese security market regularities: Monthly, turn-of-the-month and year, holiday and golden week effects. Japan and the World Economy, 3(2), 119-146.

Zikmund, W. G. (2000). Business Research Methods. 6. Edition, USA: The Dryden Press, Harcourt College Publishers. 